[Agr. Biol. Chem., Vol. 26, No. 2, p. 89 97, 1962]

\title{
Studies on the Microbiological Transformation of Steroids
}

\section{Part VI. Stereospecific Reduction of the 2o-Carbonyl Group by Fungi}

\author{
By Takeshi Takahashi and Yuji Uchibori \\ Institute for Fermentation, Osaka
}

Received August 28, 1961

\begin{abstract}
The microbiological reduction of the 20-carbonyl group of steroids has been investigated. Candida pulcherrima IFO 0964 and Sporotrichum gougeroti IFO 5982 converted the following substrates into the corresponding $20 \beta$-hydroxy derivatives (yields of the products are indicated in parentheses): Reichstein's Compound $\mathrm{S}(60 \sim 70 \%)$ and $17 a, 21$-dihydroxypregna-1,4-diene3,20-dione $(40 \sim 80 \%)$. Rhodotorula glutinis IFO 0395 converted the following substrates into the corresponding $20 a$-hydroxy derivatives: Reichstein's Compound S (65\%), 17a,21-dihydroxypregna-1,4-diene-3,20-dione $(80 \%), 11_{\beta}, 17_{\alpha}$-dihydroxypregn-4-ene-3,20-dione $(45 \%)$ and $17 \alpha$, 19,21-trihydroxypregn-4-ene-3,20-dione (10\%).
\end{abstract}

Microorganisms belonging to genus Streptomyces, such as St. lavendulae ${ }^{1)}$, St. coelicolor ${ }^{2)}$, St. hydrogenans ${ }^{3)}$, St. griseus $^{4)}$ are well known to be the 20-carbonyl reducing organism; i.e. they reduce most pregnane steroids to the corresponding 20 $\beta$-hydroxysteroids.' In addition to them Fusarium $^{5)}$, Calonectria ${ }^{5)}$, Pseudomonas $^{8)}$, Gleosporium $^{7)}$, Pythium $^{8)}$ and Stereum $^{9)}$ have been reported to have a reducing power similar to that of Streptomyces. Fusarium, Calonectria, Pseudomonas and Gleosporium, however, oxidize another site of the same compound concomitantly. On the other hand, Pythium and Stereum act only on

\footnotetext{
1) J. Fried, R.W. Thoma and A. Klingsberg, J. Am. Chem. Soc., 75, 5764 (1953).

2) E. Vischer, Ch. Meystre and A. Wettstein, Experientia, 11, 465 (1955).

3) F Lindner, R. Junk, G. Nesemann and J. Schmidt-Thomé, HoppeSeylers Z. physiol. Chem., 313, 117 (1958).

4) F. Carvajal, O.F. Vitale, M.J. Gentles, H.L. Herzog and B. Hershberg, J. Org. Chem., 24, 691 (1959).

5) S.A. Szpilfogel, P.A. Van Hemert and M.S. De Winter, Rec. trav. chim., 75, 1227 (1956).

f) H. Nawa, M. Uchibayashi, R. Takeda, J. Nakanishi, J. Terumichi, M Uchida,

M. Katsumata, K. Yoshino and H. Fujitani, Tetrahedron, 4, 201 (1958).

7) E. Kondo and E. Masuo, J. Agr. Chem. Soc. Japan, 34, 759 (1960).

8) M. Shirasaka and M. Ozaki, ibid., 35, 206 (1961).

9) T. Takahashi, Y. Uchibori and T. Hasegawa, ibid., 36, 67 (1962).
}

certain compounds. It may be therefore, said that useful microorganisms for the conversion of the 20-carbonyl group of steroids into the corresponding $20 \beta$-hydroxyl group generally belong to the Streptomyces group. As a microorganism which reduces 20-oxosteroids to the corresponding 20a-hydroxysteroids is known only one microorganism, Rhodotorula longissima. In our study on the microbiological transformation of steroids Candida pulcherrima IFO 0964 and Sporotrichum gougeroti IFO 5982 were found to reduced the 20-carbonyl group to the $20 \beta$-hydroxyl group, and Rhodotorula glutinis IFO 0935 to reduce the group to the 20a-hydroxyl group in good yields. Using these organisms the authors obtained various 20-hydroxysteroids including a new compound from the corresponding 20-oxosteroids.

As to the fermentation of steroids the details will be described in the experimental part but an evidence should be mentioned here that no influence of $\mathrm{pH}$ of culture broth on the reduction was observed in the range 
TABle I. The Influence OF PH ON THE REDUCING POWER OF THE WASHed Gell SUSPENSIONS

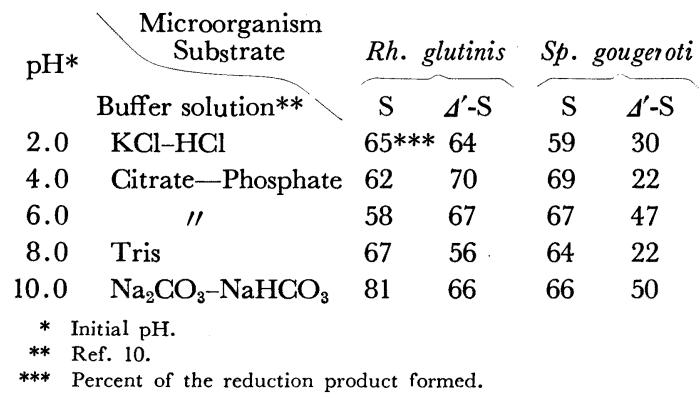

from $\mathrm{pH} 2$ to $\mathrm{pH} 10$ with any organism (Table 1).

Reductions of Reichstein's Compound S (I) and 17a,21-dihydroxypregna-1,4-diene-3,20dione (II) with $C$. pulcherrima IFO 0964, Sp. gougeroti IFO 5982 and Rh. glutinis IFO 0395 and subsequent paper chromatography of the products afforded the papergrams shown in Fig. 1, in which (a) is concerned with the experiments using $I$ as substrate and (b) with the experiments using II as substrate. Figs. (a) and (b) show that all the organisms used converted I and II into materials of $R_{F} \quad 0.7$ and $R_{F} 0.5$ (E-E solvent system), respectively. These spots were regarded as those of reduction products at the C-20 position because of their failure to develop a red color with triphenyltetrazolium chloride (TPTZ) reagent.

Through the fermentation with either $C$. pulcherrima or Sp. gougeroti I was converted into a material (III) of m.p. $188 \sim 190^{\circ} \mathrm{C}$ and II into a material (V) of m.p. $193 \sim 195^{\circ} \mathrm{C}$. On the other hand, in the case of fermentation with $R h$. glutinis, I was converted into a material (IV) of m.p. $220 \sim 222^{\circ} \mathrm{C}$ and II was

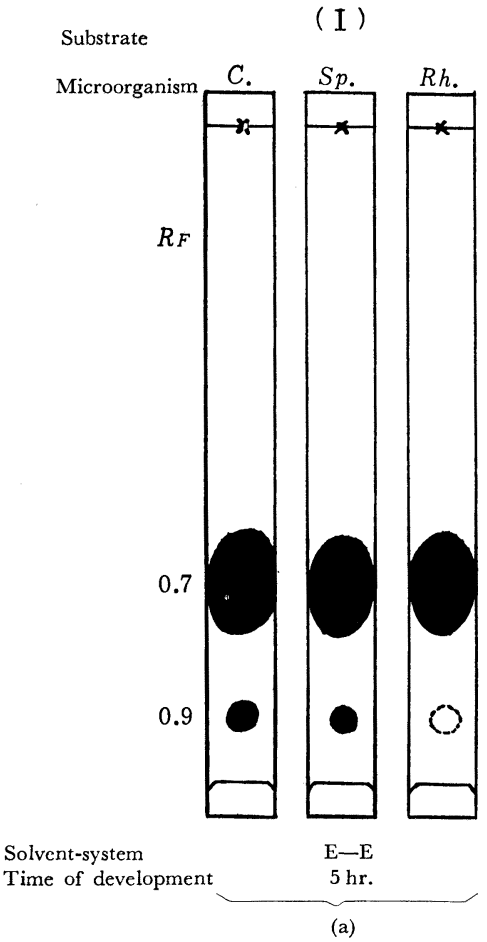

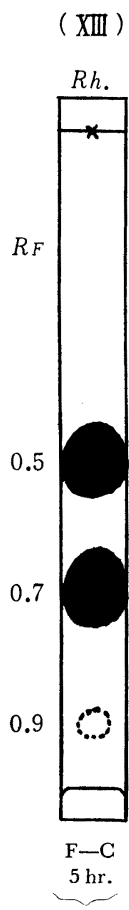

(c)

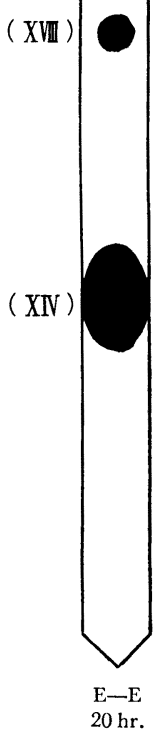

(d)

FiG. 1. Paper Chromatograms of Reduction Products. 
converted into a material (VI) of m.p. 212 $213^{\circ} \mathrm{C}$. Both the materials III and IV, analyses of which agreed with the molecular formula of $\mathrm{C}_{21} \mathrm{H}_{32} \mathrm{O}_{4}$, showed no absorption band of the 20-carbonyl in their infrared spectra and gave androst-4-ene-3,17-dione (VII) by oxidation either with sodium bismuthate or with periodic acid. Based on these observations III and IV were established to be the 20-epimers of 17a,20-21-trihydroxypregn-4-en-3-one to each other. Since both the materials $\mathrm{V}$ and $\mathrm{VI}$ analyses of which fit the same formula $\mathrm{C}_{21} \mathrm{H}_{30} \mathrm{O}_{4}$, showed no absorption band of the 20-carbonyl group in their infrared spectra and through periodic acid oxidation gave androsta-1,4-diene-3,17dione (VIII), which was in accord with the oxidation product of II by sodium bismuthate, they also were characterized as the 20 epimers of 17a,20,21-trihydroxypregna-1,4diene-3-one to each other.

An attempt was then made to determine the 20-configuration of the two sets of 20-epimers. When acetylated, III gave a diacetate (IX) of m.p. $178 \sim 180^{\circ} \mathrm{C}$ and IV gave a diacetate (X) of m.p. $245 \sim 247^{\circ} \mathrm{C}$. A comparison of properties of III, IV, IX and X with those ${ }^{11)}$ of authentic samples led to the conclusion that III and IX were 17a,20 $\beta, 21$-trihydropregn-4en-3-one and its 20 $\beta, 21$-diacetate, respectively and IV and $\mathrm{X}$ were 17a,20a,21-trihydroxypregn-4-en-3-one and its 20a,21-diacetate, respectively.

When another set of 20-epimers, V and VI,
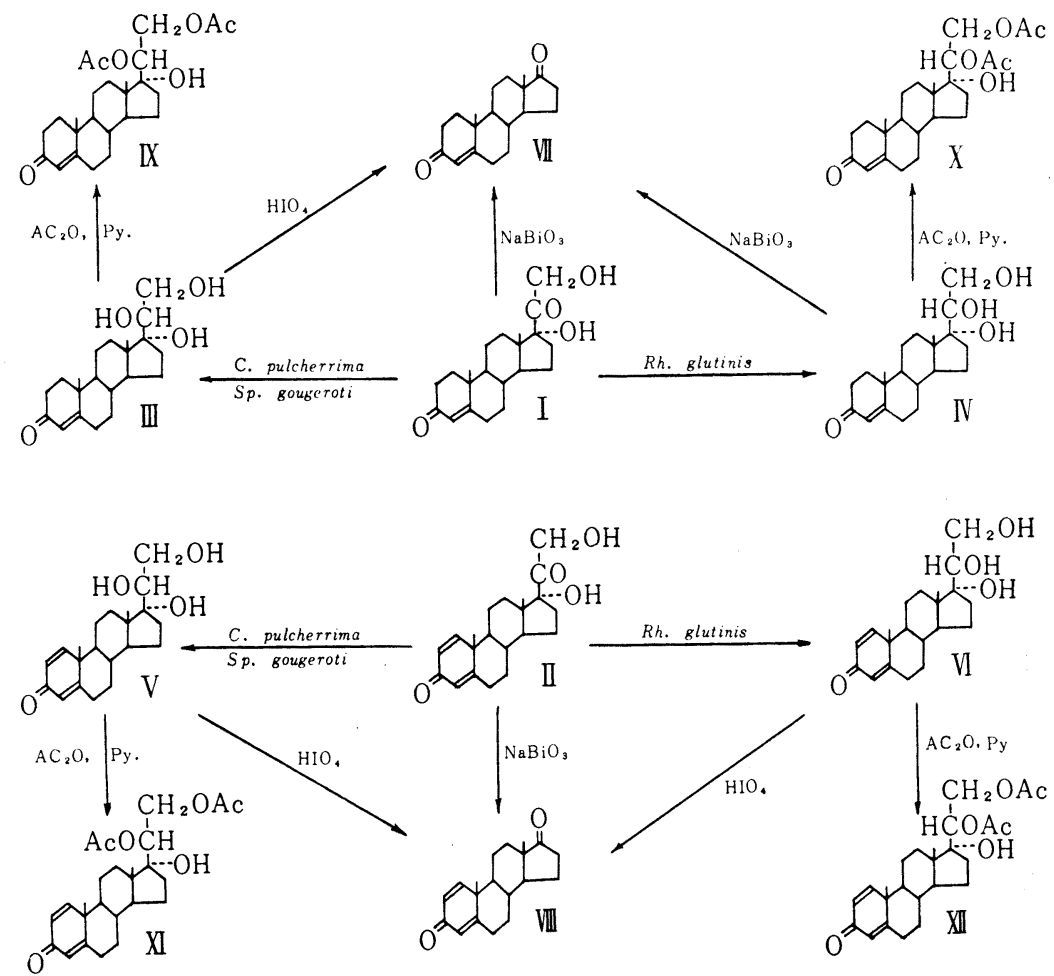

FIG. 2 . 
were acetylated, $\mathrm{V}$ gave a material (XI) of m.p. $178 \sim 180^{\circ} \mathrm{C}$ and VI afforded a diacetate (XII) of m.p. $200 \sim 202^{\circ} \mathrm{C}$. Since properties of $\mathrm{V}$ and $\mathrm{XI}$ well agreed with those ${ }^{9)}$ of 17a,20 $\beta, 21$-trihydroxypregna-1,4-dien-3-one and its diacetate, a comparison was made between $\mathrm{V}$ and an authentic sample of 17a,20, 21 -trihydroxypregna-1,4-dien-3-one and their identity was established by mixed m.p. and comparison of their infrared spectra. And therefore, the materials VI and XII should be $17 a, 20 a, 21$-trihydroxypregna-1,4-dien-3-one and its 20a,21-diacetate, respectively. These materials the infrared spectra of which are shown in Fig. 2 are new compounds.

In order to confirm the above assignment, increments of molecular rotation ${ }^{12)}$ of III, IV, $\mathrm{V}$ and VI on acetylation were measured. The
TABLE II. ASSignMent OF THE 20-CONFIgURATIVE of the Reduction Products By THE Method of MOLECULAR ROTATION DIFFERENCES

$\begin{array}{ccccc}\begin{array}{c}\text { Reduction } \\ \text { Product }\end{array} & \mathrm{M}_{\mathrm{D}}^{\text {Acetate }} & \mathrm{M}_{\mathrm{D}}^{\text {Alcohol }} & \Delta^{20}+\Delta^{21} & \begin{array}{c}\text { Configuration* } \\ \text { of the 20-ol }\end{array} \\ \text { III } & 588 & 268 & +320 & \beta \\ \text { IV } & 100 & 208 & -108 & \boldsymbol{\alpha} \\ \text { V } & 426 & 59 & +367 & \beta \\ \text { VI } & -95 & 45 & -140 & \boldsymbol{\alpha}\end{array}$

$\Delta=\mathrm{M}_{\mathrm{D}}^{\text {Acetate }}-\mathrm{M}_{\mathrm{D}}^{\text {Alcohol }}$

* Since the absolute value of the $\Delta^{21}$ is small, the sign of the $\Delta^{20}$ is in accord with that of the $\Delta^{20}+\Delta^{21}$. (Ref. 13)

calculation supported the previous assignment that III and V were $20 \beta$-ols and IV and VI were 20a-ols (Table II).

From the results mentioned above it became clear that Candida pulcherrima and Sporotrichum gougeroti reduced I and II to the corresponding $20 \beta$-ols (in $40 \sim 80 \%$ yields) and

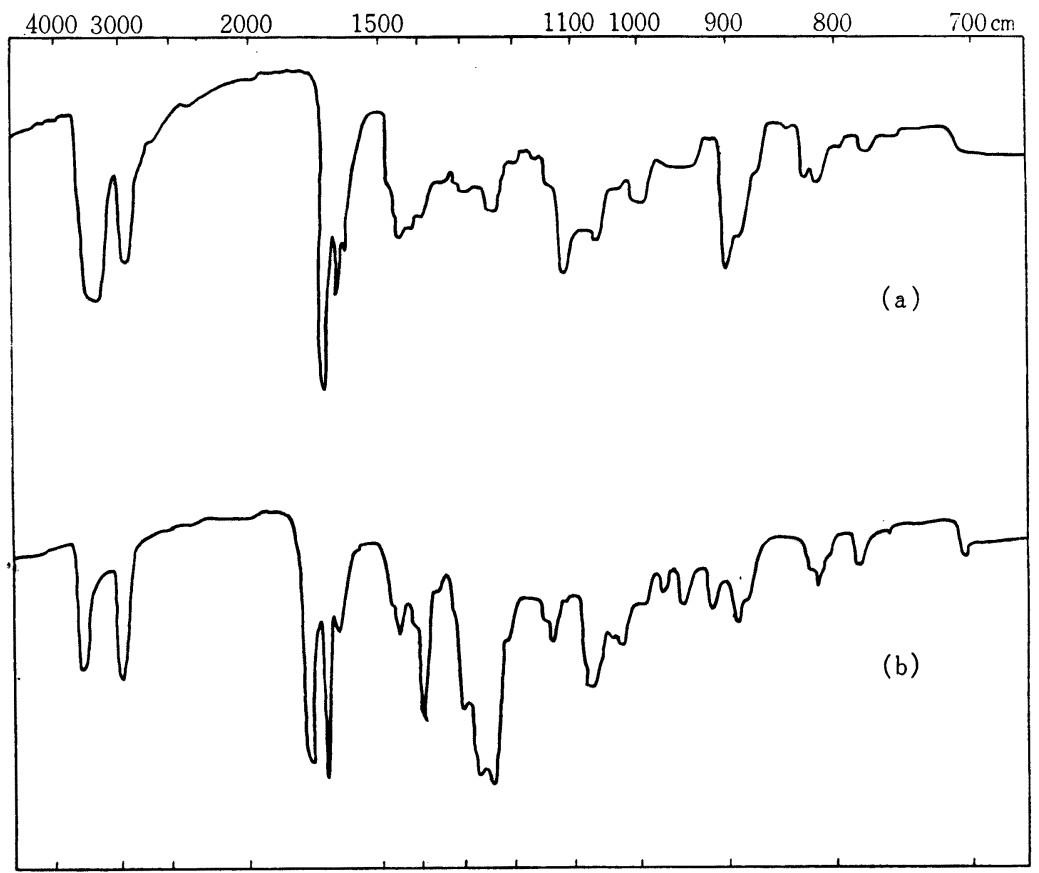

FIG. 3. The Infrared Absorption Spectra of (a), 17 $\alpha, 20 \alpha, 21$-Trihydroxypregna-1,4-dien-3-one (VI) and (b), 20 $\alpha, 21$-Diacetoxypregna-1,4-dien-17 $\alpha$-ol-3-one (XII). 
that Rhodotorula glutinis converted I and II into the corresponding 20a-ols (in 60 80\% yields).

Further using $R h$. glutinis an attempt was made to convert $11 \beta, 17 \alpha$-dihydroxypregn-4-ene3,20-dione (XIII) and 17a,19,21-trihydroxypregn-4-ene-3,20-dione (XIV) into the corresponding 20a-ols. Figs. 1c and ld show the papergrams of fermentation products of XIII and XIV, respectively. From the fermentation of XIII two materials, $R_{F}$ 's of which were 0.7 and 0.5 on the papergram (F-C system), were isolated in yields of $40 \%$ and $45 \%$ through a column chromatography over Florisil. By periodic acid oxidation the less polar product (XV) of m.p. $209 \sim 210^{\circ} \mathrm{C}$ gave rise to a material of m.p. $191 \sim 192^{\circ} \mathrm{C}$, which was identical with $11 \beta$-hydroxandrost-4-ene3,17-dione (XVI) produced through oxidation of hydrocortisone with sodium bismuthate. On acetylation $\mathrm{XV}$ afforded monoacetate
$20 a$-acetate. The structure of the more polar products remains to be established.

XIV was converted with difficulty and the conversion ratio was $1 / 10$ after seven day incubation with $R h$. glutinis. The mobility of the conversion product (XVIII) on the papergram (E-E solvent system) was one-sixth of that of XIV and coincided with that of $17 a, 19,20 a$, 21-tetrahydroxypregn-4-en-3-one ${ }^{14)}$. Negative TPTZ reaction supported that XVIII was a reduction product at the C-20 position of XIV. $11 \beta, 17 a, 20 a$-trihydroxypregn-4-en-3-one and its

\section{EXPERIMENTAL*}

Microorganisms : Candida pulcherrima IFO 0964 Sporotrichum gougeroti IFO 5982 Rhcdotorula glutinis IFO 0395

Fermentation of Steroids with the Microorganisms.

(a) With $\boldsymbol{C}$. pulcherrima or Rh. glutinis. Fifty milliliters of a medium containing $100 \mathrm{~g}$ of sucrose, $3 \mathrm{~g}$ of ammonium sulfate, $2 \mathrm{~g}$ of magnesium sulfate, $5 \mathrm{~g}$ of potassium phosphate, mono-basic, and $10 \mathrm{ml}$ of vitamin solution $^{15)}$ in 11 of tap water were sterilized
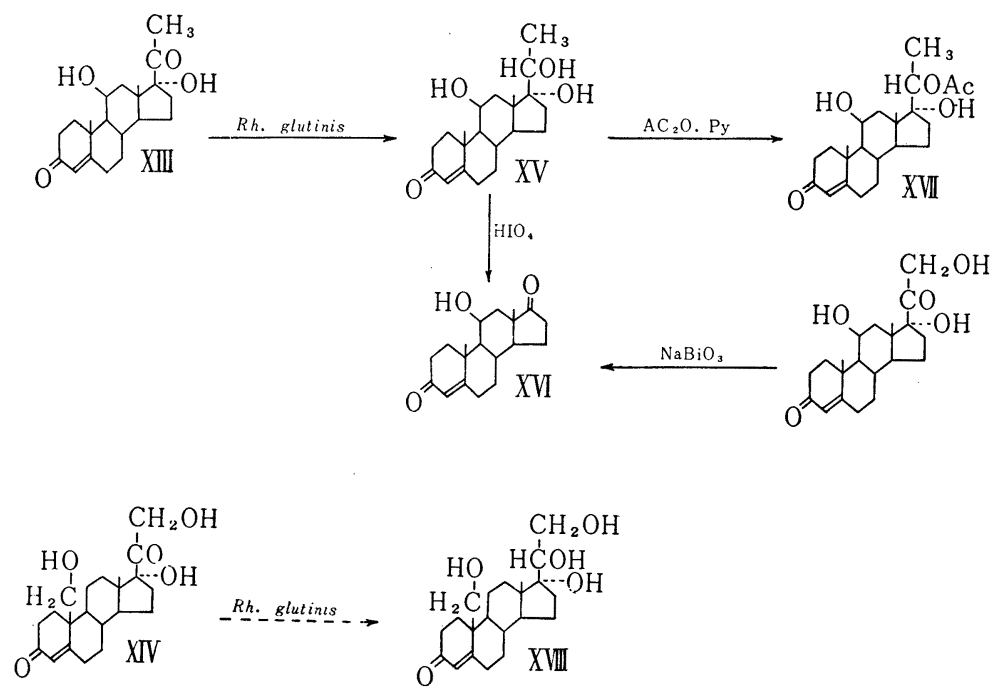

FIG. 4.

(XVII) of m.p. $223 \sim 228^{\circ}$ C. Properties of $\mathrm{XV}$ and XVII well agreed with those of

\footnotetext{
14) T. Takahashi, This Journal, in press.

15) T. Hasegawa and T. Takahashi, ibid., 23, 137 (1959).

* All melting points are uncorrected.
} 
under 15 pound steam pressure for fifteen minutes, inoculated with a lump of cells of a given organism, and incubated at $28^{\circ} \mathrm{C}$ on a rotary shaker for three days. The culture was aseptically poured into an Erlenmeyer flask containing $400 \mathrm{ml}$ of the same medium and further incubated for three days. To the culture $50 \sim 100 \mathrm{mg}$ of a substrate as fine powders was added and incubation was continued aerobically for two to seven days. Reduction products were extracted from the culture broth with an equal volume of ethyl acetate. The ethyl acetate extract was washed with $5 \%$ sodium bicarbonate solution and water, dried with anhydrous sodium sulfate and evaporated to dryness. The residue was examined through paper chromatography and then was treated with convenient techniques for isolation of the products.

(b) With Sp. gougeroti. Fifty milliliters of a medium containing $30 \mathrm{~g}$ of glucose, $3 \mathrm{~g}$ of corn steep liquor, $15 \mathrm{~g}$ of polypeptone in 11 of tap water were inoculated with a lump of mycelium of $S p$. gougeroti IFO 5982 and incubated at $28^{\circ} \mathrm{C}$ on a reciprocating shaker for five days. To $400 \mathrm{ml}$ of the same medium the culture was added aseptically and further incubated for three days. At this point of shaking culture $50 \sim$ $100 \mathrm{mg}$ of a substrate was added to the culture and incubation was continued for two to five days. Treatment of the reaction mixture was the same as that in the case of $C$. pulcherrima.

(c) Influence of $\mathrm{pH}$ on the Reduction by the Microorganisms. In order to examine influences of the $\mathrm{pH}$ of a reaction mixture on the reduction proces the microbiological reduction was conducted with washed cell suspensions of $R h$. glutinis or Sp. gougeroti in buffer solutions of various pH's. According to the procedures mentioned above, 0.51 of each culture was incubated. From the culture broths the mycelia were harvested by centrifugation (in the case of $R h$. glutinis) or by filtration (in the case of $S p$. gougeroti) and washed with 0.51 of water two times. Each mycelium thus obtained was divided equally into 10 Erlenmyer flasks containing $50 \mathrm{ml}$ of a buffer solution. To each flask was added a solution of $5 \mathrm{mg}$ of either Reichstein's Compound $S$ (I) or 17a,21dihydroxypregna-1,4-diene-3,20-dione (II) dissolved in $0.5 \mathrm{ml}$ of ethanol and the mixture was incubated on a rotary shaker for twenty-four hours. For quantitative measurements of reaction products was made use of a method through paper chromatography as mentioned below. The result of this experiment is shown in Table II. Both organisms showed no remarkable fluctuation in their strong reducing powers between $\mathrm{pH} 2$ and 10. Sp. gougeroti was different from $R h$. glutinins, which easily reduced both $\mathbf{I}$ and II, in that the ofrmer showed much weaker reducing power on II than on I.

Examination and Quantitative Measurements of Reduction Products through Paper Chromatography.

A reaction mixture was extracted with a solvent and the steroid fraction after evaporation of the solvent was dissolved in acetone. A definite volume of the acetone solution containing $100 \gamma$ of steroids was pipetted and applied on the starting point of a paper strip (Whatman No. 1). Then the paper was chromatographed with a solvent system such as ethylene glycol/ethylene chloride (E-E system) ${ }^{18)}$ or formamide/ chloroform (F-C system) ${ }^{17}$. For detection of spots UV absorption was used. In order to differentiate spots of reduction products from other spots the color reaction with TPTZ reagent ${ }^{18)}$ was made use of. The following procedure was used for quantitative evaluation of unreacted substrate and reduction products. A desired spot of the papergram was cut off carefully and eluted with $5 \mathrm{ml}$ of methanol. Absorbancy of the methanol solution was measured spectrophotometrically at the wave length of maximum absorption, e.g. at $240 \mathrm{~m} \mu$ in the case of $a, \beta$-unsaturated oxosteroids. Using the value as well as the molecular extinction coefficient of the compound the amount of the steroid contained in the methanol solution was calculated.

\section{$17 \alpha, 20 \beta, 21$-Trihydroxypregn-4-en-3-one (III).}

(a) Reduction of I by C. pulcherrima. According to the procedure mentioned above, 101 of the culture of C. pulcherrima IFO 0964 were prepared. To the culture was added $2.6 \mathrm{~g}$ of. I and incubation was continued aerobically for seven days. The crude product obtained by extraction of the reaction mixture was dissolved in ethylene chloride, charged on the top of a column prepared by filling up with $100 \mathrm{~g}$ of Florisi] and developed with solvents varying proportions of acetone in ethylene chloride. Paper chromatography of the eluates showed that small amounts of unreacted substrate was eluted with $2 \sim 10 \%$ acetone in ethylene chloride and the reduction product desired was eluted

16) T. Takahashi and T. Heasegawa, J. Agr. Chem. Soc. Japan, 35, 1394 (1961).

17) A. Zaffaroni, R.B. Burton and E.H. Keutmann, Science, 111, 6 (1950).

18) R.B. Burton, A. Zaffaroni and E.H. Keutmann, J. Biol. Chem., 188, 763 (1951). 
with $15 \sim 40 \%$ acetone in ethylene chloride. The fractions containing the product were combined and concentrated to give $1.6 \mathrm{~g}$ of crude crystals which were recrystallized from acetone to yield $17 a, 20 \beta, 21$-trihydroxypregn-4-en-3-one (III) of m.p. $188 \sim 190^{\circ} \mathrm{C}$, $[\alpha]_{\mathrm{D}}^{21}+77^{\circ} \quad(\mathrm{c}=1.0$, chloroform $), \quad \lambda_{\max }^{\mathrm{EtOH}} 241 \mathrm{~m}_{\mu} \quad(\epsilon$, $15,800), \quad \nu_{\max }^{\mathrm{KBr}} 3450(\mathrm{OH}), 1650,1618 \mathrm{~cm}^{-1} \quad\left(\Delta^{4}-3-\right.$ CO). Anal. Found: C, 72.36; H, 9.17. Calcd. for $\mathrm{C}_{21} \mathrm{H}_{32} \mathrm{O}_{4}$ : C, 72.38; $\mathrm{H}, 9.26 \%$.

(b) Reduction of I by Sp. gougeroti. To 41 of the culture of $S p$. gougeroti IFO 5982 was added I (1 g) and incubation was continued aerobically for a period of three days. The ethyl acetate extract from the reaction mixture was chromatographed over Florisil using ethylene chloride-acetone mixture for elution. Fractions containing the reduction product were combined and concentrated with concurrent crystallization of the product. The crude crystal $(520 \mathrm{mg})$ was recrystallized from acetone to give $17 a, 20 \beta, 21$-trihydroxypregn-4-en-3-one (III) of m.p. $188 \sim 190^{\circ} \mathrm{C}$. This material had an infrared spectrum identical with that of the reduction product by $C$. pulcherrima and the mixed melting point of these two samples showed no depression.

$17 \alpha, 20 \alpha, 21$-Trihydroxypregen-4-en-3-one (IV).

To 41 of the culture of Rh. glutinis IFO 0395 was added $\mathrm{I}(\mathrm{lg})$ dissolved in $30 \mathrm{ml}$ of ethanol and aerobical incubation was continued for three days. Extraction of the reduction mixture with ethyl acetate, followed by concentration gave crude crystals $(650 \mathrm{mg}$ ) which by recrystallization from ethanol afforded $17 a$, 20a,21-trihydroxypregn-4-en-3-one (IV) of m.p. 220 $222^{\circ} \mathrm{C},[\alpha]_{\mathrm{D}}^{22}+60^{\circ}$ (c=1.0, ethanol), $\lambda_{\max }^{\mathrm{EtOH}} 242 \mathrm{~m} \mu$ $(\epsilon, 15,500), \nu_{\max }^{\mathrm{KBr}} 3330(\mathrm{OH}), 1661,1618 \mathrm{~cm}^{-1}\left(\Delta^{4}-\right.$ 3-CO). A mixture of this material and III showed depression in M.p. Anal. Found: C, 72.41; H, 9.26. Calcd. for $\mathrm{C}_{21} \mathrm{H}_{32} \mathrm{O}_{4}$ : C, 72.38; $\mathrm{H}, 9.26 \%$.

17 $\alpha, 20 \beta, 21-T r i h y d r o x y p r e g n a-1,4-d i e n-3-o n e(V)$.

(a) Reduction of II by C. pulcherrima. To 51 of the culture of $C$. pulcherrima was added II (1.2 g) dissolved in $120 \mathrm{ml}$ of ethanol and incubation was continued for forty-eight hours. After extraction with ethyl acetate, the reduction product was purified through column chromatography over Florisil. Fifty percent acetone in methylene chloride and acetone eluted a crude crystal $(850 \mathrm{mg})$, which was recrystallized from methanol- $n$-hexane to give $17_{\alpha, 20}, 21$-trihydroxypregna-1,4-dien-3-one (V) containing one mole of methanol of crystallization, m.p. $191 \sim 193^{\circ} \mathrm{C}$. Anal. Found: C, 70.12; $\mathrm{H}, 9.24$. Calcd. for $\mathrm{C}_{21} \mathrm{H}_{30} \mathrm{O}_{4} \cdot \mathrm{CH}_{3} \mathrm{OH}$ : C, $69.81 ; \mathrm{H}, 9.05 \%$.

When recrystallized from ethyl acetate, this material gave rise to $\mathrm{V}$ of m.p. $193 \sim 195^{\circ} \mathrm{C},[\alpha]_{\mathrm{D}}^{21}+17^{\circ}(\mathrm{c}=1.0$, chloroform), $\lambda_{\max }^{\mathrm{EtOH}} 246 \mathrm{~m}_{\mu} \quad(\epsilon, 15,200), \quad \nu_{\max }^{\mathrm{KBr}} 3390$ $(\mathrm{OH}), 1656,1613,1600 \mathrm{~cm}^{-1}\left(\Delta^{1,4}-3-\mathrm{CO}\right) . \quad$ Anal. Found: $\mathrm{C}, 72.92 ; \mathrm{H}, 8.92$. Calcd. for $\mathrm{C}_{21} \mathrm{H}_{30} \mathrm{O}_{4}$ : $\mathrm{C}$, $72.80 ; \mathrm{H}, 8.73 \%$.

(b) Reduction of II by Sp. gougeroti. From 41 of the culture of $S p$. gougeroti the mycelium was harvested through filtration, washed twice with 41 of water and suspended in 41 of a citrate-phosphate buffer solution ( $\mathrm{pH} 6.0$ ). To the cell suspension was added II ( $1 \mathrm{~g})$ as fine powders and incubation was continued on a reciprocating shaker for twenty-four hours. An ethyl acetate extract from the reaction mixture was chromatographed over Florisil using methylene chloride and methylene chloride-acetone mixture. Elution with methylene chloride-acetone gave $290 \mathrm{mg}$ of $17 a$, 20 $\beta$,21-trihydroxypregna-1,4-dien-3-one (V) , m.p. 192 $193^{\circ} \mathrm{C}$. This material showed no depression in melting point on admixture with the material produced through the action of $C$. pulcherrima on II and the infrared spectra of the two were identical. In addition to $\mathrm{V}$ a considerable amount of the starting material was recovered in this experiment.

\section{7 $\alpha, 20 \alpha, 21-T r i h y d r o x y p r e g n a-1,4-d i e n-3-o n e$ (VI).}

To 41 of the culture of Rh. glutinis was added II ( $1 \mathrm{~g})$ dissolved in $30 \mathrm{ml}$ of ethanol and incubation was continued for seven days. The ethyl acetate extract from the reaction mixture was concentrated and cooled to give a crude crystal, which was recrystallized from acetone to give rise to $550 \mathrm{mg}$ of $17 a, 20 \beta, 21$-trihydroxypregna-1,4-dien-3-one (VI), m.p. $212 \sim 213^{\circ} \mathrm{C}$, $[\alpha]_{\mathrm{D}}^{21}+13^{\circ} \quad\left(\mathrm{c}=0.8\right.$, chloroform), $\lambda_{\max }^{\mathrm{EtOH}} 245 \mathrm{~m} \mu$ (e, $15,400), \nu_{\max }^{\mathrm{KBr}} 3390(\mathrm{OH}), 1670,1630,1608 \mathrm{~cm}^{-1}\left(\Delta^{1,4}\right.$ 3-CO). Anal. Found: C, 72.89; H, 8.73. Calcd. for $\mathrm{C}_{21} \mathrm{H}_{30} \mathrm{O}_{4}: \mathrm{C}, 72.80 ; \mathrm{H}, 8.73 \%$.

Androst-4-ene-3,17-dione (VII).

(a) Two hundred milligrams of I dissolved in $10 \mathrm{ml}$ of gracial acetic acid and $10 \mathrm{ml}$ of water was allowed to react with $2 \mathrm{~g}$ of sodium bismuthate ${ }^{19 \lambda}$ with stirring for two hours. The reaction mixture was neutralized with potassium hydroxide and extracted with methylene chloride. The methylene chloride

19) C.J.W. Brooks and J.K. Norymberski, Biochem. J., 55, 371 (1953). 
sidue after recrystallization from acetone afforded androst-4-ene-3,17-dione (VII), m.p. $178 \sim 180^{\circ} \mathrm{C},[\alpha]_{\mathrm{D}}^{21}$ $+193^{\circ}$ (c=10, chloroform), $\lambda_{\max }^{\mathrm{EtOH}} 239 \mathrm{~m}_{\mu} \quad(\epsilon, 16,200)$, $\nu_{\max }^{\mathrm{KBr}} \quad 1739 \quad(17-\mathrm{CO}), 1667,1618 \mathrm{~cm}^{-1} \quad\left(\Delta^{4}-3-\mathrm{CO}\right)$. Anal. Found: C, 79.45; H, 8.92. Calcd. for $\mathrm{C}_{19} \mathrm{H}_{26} \mathrm{O}_{2}$ : C, $79.68 ; \mathrm{H}, 9.15 \%$.

(b) To $105 \mathrm{mg}$ of III dissolved in $4.5 \mathrm{ml}$ of dioxane was added a solution of $150 \mathrm{mg}$ of periodic acid $^{20)}$ in $1.5 \mathrm{ml}$ of water. After being kept at room temperature for eighteen hours, the reaction mixture was extracted with methylene chloride. The residue obtained after evaporation of the methylen chloride extract was purified through a column chromatography on Florisil and crystallized from ether- $n$ hexane to yield a material of m.p. $166 \sim 168^{\circ} \mathrm{C}$. A mixture of this material with VII showed no depression in melting point and its infrared spectrum was identical with that of VII.

(c) Fifty-three milligrams of IV was oxidized with $1 \mathrm{~g}$ of sodium bismuthate in the $50 \%$ aqueous acetic acid solution. The oxidation product was crystallized from methylene chloride-ether to afford a material melting at $160 \sim 166^{\circ} \mathrm{C}$. The infrared spectrum of this material was also identical with that of VII.

Androsta-1,4-diene-3,17-dione (VIII).

(a) Five hundred milligrams of II was oxidized with $5 \mathrm{~g}$ of sodium bismuthate in the $50 \%$ aqueous acetic acid solution. Purification of the oxidation product through a column chromatography on Florisil and subsequent crystallization from methylene chlorideether gave rise to androsta-1,4-diene-3,17-dione (VIII), m.p. $139 \sim 141^{\circ} \mathrm{C}, \quad[\alpha]_{\mathrm{D}}^{21}+114^{\circ} \quad(\mathrm{c}=1.0$, chloroform), $\lambda_{\max }^{\mathrm{EtOH}} 243 \mathrm{~m}_{\mu}(\epsilon, 14,800), \nu_{\max }^{\mathrm{KBr}} 1745 \quad(17-\mathrm{CO}), 1667$, $1631,1610 \mathrm{~cm}^{-1}\left(\Delta^{1,4}-3-\mathrm{CO}\right)$. Anal. Found: C, 80.51; $\mathrm{H}$, 8.45. Calcd. for $\mathrm{C}_{19} \mathrm{H}_{24} \mathrm{O}_{2}$ : C, 80.24; $\mathrm{H}, 8.51 \%$.

(b) Fifty milligrams of $\mathrm{V}$ in dioxane was oxidized with $80 \mathrm{mg}$ of periodic acid. The reaction product was crystallized from acetone- $n$-hexane to give a material of m.p. $110 \sim 115^{\circ} \mathrm{C}$, which was identical with the material produced by oxidation of VI with periodic acid. This material had the infrared spectrum identical with that of VIII.

20 $\beta$,21-Diacetoxypregn-4-en-17 $\alpha$-ol-3-one (IX).

One hundred and thirty-five milligrams of III was acetylated with $4 \mathrm{ml}$ of acetic anhydride and $2 \mathrm{ml}$ of pyridine. Crystallization of the product from acetone

20) A. Larden, Helv. Chim. Acta, 34, 756 (1951). gave 20 $\beta, 21$-diacetoxypregn-4-en-17 $a$-ol-3-one (IX) of m.p. $178 \sim 180^{\circ} \mathrm{C}, \quad[\alpha]_{\mathrm{D}}^{21}+136^{\circ} \quad(\mathrm{c}=1.0$, chloroform $)$, $\lambda_{\max }^{\mathrm{EtOH}} 241 \mathrm{~m}_{\mu} \quad(\epsilon, 15,600), \quad \nu_{\max }^{\mathrm{KBr}} 3484 \quad(\mathrm{OH}), 1751$ (acetyl-CO) $1667,1629\left(\Delta^{4}-3-\mathrm{CO}\right), 1242,1224 \mathrm{~cm}^{-1}$ (C-O-C) . Anal. Found: C, 69.45; H, 8.57. Calcd. for $\mathrm{C}_{25} \mathrm{H}_{36} \mathrm{O}_{3}: \mathrm{C}, 69.42 ; \mathrm{H}, 8.39 \%$.

20 $\alpha, 21$-Diacetoxypregn-4-en-17 $\alpha$-ol-3-one (X).

Four hundred milligrams of IV was dissolved in $4 \mathrm{ml}$ of pyridine and $2 \mathrm{ml}$ of acetic anhydride. The solution was allowed to stand at room temperature overnight. Dilution of the mixture with water and subsequent cooling gave 20a,21-diacetoxypregn-4-en$17 \alpha$-ol-3-one $(\mathrm{X})$ of m.p. $245 \sim 247^{\circ} \mathrm{C}, \quad[\alpha]_{\mathrm{D}}^{22}+23^{\circ} \quad(\mathrm{c}=$ 1.0, chloroform), $\nu_{\max }^{\mathrm{KBr}} 3401(\mathrm{OH}), 1718$ (acetyl-CO), 1675, 1618 ( $\left.\Delta^{4}-3-\mathrm{CO}\right), 1253,1227 \mathrm{~cm}^{-1}$ (C-O-C). Anal. Found: $\mathrm{C}, 69.27 ; \mathrm{H}, 8.21$. Calcd. for $\mathrm{C}_{25} \mathrm{H}_{36} \mathrm{O}_{6}$ : C, 69.42; H, $8.39 \%$.

20 $\beta, 21-D i a c e t o x y p r e g n a-1,4-d i e n-17 \alpha$-ol-3-one (XI).

One hundred milligrams of $\mathrm{V}$ was acetylated with $4 \mathrm{ml}$ of pyridine and $4 \mathrm{ml}$ of acetic anhydride. Crystallization of the product from methylene chlorideether gave $20 \beta, 21$-diacetoxypregna-1,4-dien-17 $\alpha$-ol-3-one (XI) of m.p. $178 \sim 180^{\circ} \mathrm{C}, \quad[\alpha]_{\mathrm{D}}^{21}+99^{\circ}(\mathrm{c}=1.0$, chloroform), $\nu_{\max }^{\mathrm{KBr}} 3521(\mathrm{OH}), 1739$ (acetyl-CO), 1667, 1631, 1608 ( $\left.\Delta^{1,4-3-C O}\right), 1241,1225,1217 \mathrm{~cm}^{-1}$ (C-O-C), Anal. Found: C, 69.61; $\mathrm{H}, 7.75$. Calcd. for $\mathrm{C}_{25} \mathrm{H}_{34} \mathrm{O}_{6}$ : C, $69.74 ; \mathrm{H}, 7.96 \%$.

20 $\alpha, 21-D i a c e t o x y p r e g n a-1,4-d i e n-17 \alpha$-ol-3-one (XII).

Sixty milligrams of the VI was dissolved in $1 \mathrm{ml}$ of pyridine and $2 \mathrm{ml}$ of acetic anhydride. The solution was kept at room temperature for 24 hours and crystallization of the product from acetone- $n$-hexane gave rise to 20a,21-diacetoxypregna-1,4-dien-17 $a$-ol-3one (XII) of m.p. $200 \sim 202^{\circ} \mathrm{C},[\alpha]_{\mathrm{D}}^{21}-22^{\circ} \quad(\mathrm{c}=0.5$, chloroform $), \quad \lambda_{\max }^{\mathrm{EtOH}} 245 \mathrm{~m}_{\mu} \quad(\epsilon, 15,500), \quad \nu_{\max }^{\mathrm{KBr}} 3472$ $(\mathrm{OH}), 1739,1727$ (acetyl-CO) $, 1678,1637,1613\left(\Delta^{1,4}\right.$ 3-CO) , 1259, $1232 \mathrm{~cm}^{-1}$ (C-O-C) . Anal. Found: C, 69.72; $\mathrm{H}$, 7.74. Calcd. for $\mathrm{C}_{25} \mathrm{H}_{34} \mathrm{O}_{6}: \mathrm{C}, 69.74 ; \mathrm{H}$, $7.96 \%$.

$11 \beta, 17 \alpha, 20 \alpha$-Trihydroxypregn-4-en-3-one (XV).

To 4.51 of the culture of Rh. glutinis was added $1 \mathrm{~g}$ of fine powders of $11 \beta, 17 a$-dihydroxypregn-4-ene-3,20dione (XIII) and incubation was continued for seven days. The reaction product was extracted with ethyl acetate. After evaporation, the ethyl acetate extract gave an oily residue, which was heated with $30 \mathrm{ml}$ of 
$n$-hexane, and the solvent was removed by decantation. Then the residue was chromatographed over Florisil using a mixture of ethyl acetate and methylene chloride. A material (A) which showed $R_{F} 0.7$ in paper chromatography (F-C system) was eluted with $30 \%$ ethyl acetate in methylene chloride and then a material (B) of m.p. $176 \sim 178^{\circ} \mathrm{C}$ which showed $R_{F} 0.5$ in the PPC was eluted with $50 \%$ ethyl acetate in methylene chloride. Recrystallization of the material A from acetone gave rise to $11 \beta, 17_{\alpha}, 20_{\alpha}$-trihydroxypregn-4-en3-one (XV), m.p. 209 210 ${ }^{\circ} \mathrm{C}, \quad[\alpha]_{\mathrm{D}}^{21}+94^{\circ} \quad(\mathrm{c}=0.5$, chloroform). Anal. Found: C, 72.38; H, 9.43. Calcd. for $\mathrm{C}_{21} \mathrm{H}_{32} \mathrm{O}_{4}: \mathrm{C}, 72.38 ; \mathrm{H}, 9.26 \%$. XV was acetylated with acetic anhydride and pyridine to give $20 a$-acetoxypregn-4-ene-11 $\beta, 17 \alpha$-diol-3-one (XVII) of m.p. $223 \sim 228^{\circ} \mathrm{C}$. The physical properties of XV and XVII were identical with those of the corresponding authentic samples ${ }^{21}$. Oxidation of $50 \mathrm{mg}$ of $\mathrm{XV}$ with periodic acid in methanol gave $11 \beta$-hydroxyandrost-4-ene-3,17dione (XVI), m.p. $191 \sim 192^{\circ} \mathrm{C}$, which was identical with that produced through oxidation of hydrocortisone with sodium bismuthate. The structure of the material $B$ remains to be elucidated.

21) G.I. Poos, J. Am. Chem. Soc., 77, 4932 (1955).
Fermentation of $7 \alpha, 19,21-T r i h y d r o x y p r e g e n-4-e n e-3,20$ dione (XIV) with $R$. glutinis.

To $50 \mathrm{ml}$ of the culture of $R h$. glutinis was added $10 \mathrm{mg}$ of $17 \alpha, 19,21$-trihydroxypregn-4-ene-3,20-dione and incubation was continued for five days. Extraction and subsequent paper chromatography (E-E system) of the product gave a paper chromatogram as shown in Fig. 1 (d). The mobility of the spot of the product was $1 / 6$ of that of the substrate and was identical with that of $17_{a}, 19,20_{a}, 21$-tetrahydroxypregn-4-en-3-one (XVIII) produced by one of the authors through microbiological transformation of $17 a, 20 a, 21$-trihydroxypregn-4-en-3-one by Pellicularia filamentosa $\mathrm{f}$. s. microsclerotia ${ }^{14)}$. Since the spot of the product showed negative color reaction with TPTZ, it was estimated to be $17 a, 19,20 a, 21$-tetrahydroxypregn-4-en3-one (XVIII).

Acknowledgement. The authors wish to express their sincerest thanks to Dr. S. Kuwada, Dr. K. Sato and Dr. T. Hasegawa for their guidance and encouragement throughout this work. They also wish to thank Dr. K. Morita for his helpful advice. 